Handini, M.A. • D. Saptadi · B. Waluyo

\title{
Parameter genetik karakter komponen hasil dan seleksi 82 genotipe ercis di dataran rendah
}

Sari. Ercis (Pisum sativum L.) ialah salah satu tanaman dari famili Fabaceae dan tergolong tanaman legume yang memiliki nilai ekonomi cukup tinggi. Studi pemuliaan tanaman pada ercis ditujukan untuk mendapat hasil yang optimal di berbagai wilayah penanaman, salah satunya dataran rendah. Keberhasilan program seleksi memerlukan parameter genetik seperti keragaman genetik dan heritabilitas. Penelitian ini bertujuan untuk mengetahui keragaman genetik dan heritabilitas karakter 82 genotipe ercis dan menentukan genotipe yang berpotensi dikembangkan di dataran rendah. Percobaan dilaksanakan berdasarkan rancangan augmented design dengan 82 genotipe uji dan tiga pembanding (cek). Karakter yang memiliki keragaman luas dan heritabilitas tinggi terdapat pada karakter bobot brangkasan daun, bobot brangkasan batang, bobot polong kering per tanaman, dan bobot biji kering per tanaman. Genotipegenotipe yang terseleksi di dataran rendah berdasarkan karakter bobot polong kering per tanaman dan bobot biji kering per tanaman ialah 03(16)(2)-1, Batu-1-1 dan Batu-2.

Kata kunci: Ercis · Keragaman genetik · Heritabilitas · Seleksi · Dataran rendah

\section{Genetic parameters of yield component characters and selection of 82 pea genotypes in lowland}

\begin{abstract}
Pea (Pisum sativum L.) is one of plants from Fabaceae family and belongs to legume crop that have high economic value. Plant breeding studies on pea are intended to obtain optimal yield in various cultivation areas, one of which is in lowland. The success of selection program requires genetic parameters such as genetic variability and heritability. The purpose of this study was to know the genetic variability and heritability of 82 pea genotypes and select the genotypes to be developed in lowland. The experiment was conducted based on the augmented design with 82 pea genotypes tested and three checks. The characters that have wide variability and high value of heritability were found in characteristics of weight of dry leaves, weight of dry stem, dry pods per plant weight and dry seeds per plant weight. The selected pea genotypes in lowland based on characteristics of dry pods per plant weight and dry seeds per plant weight were 03(16)(2)-1, Batu-1-1 and Batu-2.
\end{abstract}

Keywords: Pea · Genetic variability · Heritability · Selection · Lowland

Diterima : 22 Januari 2020, Disetujui : 10 Agustus 2020, Dipublikasikan : 12 Agustus 2020 doi: https://doi.org/10.24198/kultivasi.v19i2.22931

Handini, M.A. · D. Saptadi · B. Waluyo

Jurusan Budidaya Pertanian, Fakultas Pertanian, Universitas Brawijaya Malang

Korespondensi: darmawansaptadi@gmail.com 


\section{Pendahuluan}

Ercis ( $P$. sativum L.) ialah tanaman polongpolongan yang memiliki nilai ekonomis cukup tinggi dan banyak dimanfaatkan sebagai salah satu sumber protein nabati karena memiliki nilai gizi yang cukup tinggi, yaitu protein, karbohidrat kompleks, vitamin, dan mineral (Dahl et al., 2012). Permintaan ercis di Indonesia semakin meningkat, namun tidak diiringi ketersediaan ercis dalam negeri. Berdasarkan data Kementerian Pertanian (2017), volume impor ercis Indonesia cenderung meningkat dari tahun 2012 hingga 2016. Volume impor tahun 2012 sebesar 19.343 ton dan meningkat mencapai 23.038 ton pada tahun 2014. Peningkatan volume ercis terjadi pada tahun 2015 hingga tahun 2016 sebesar 9,2\%.

Sentra produksi dan budidaya tanaman ercis di Indonesia selama ini masih dilakukan di dataran tinggi (Purnamaningsih et al., 2019; Waluyo et al., 2019). Hal ini merupakan faktor pembatas bagi peningkatan produksi. Ekspansi wilayah penanaman ke daerah dataran medium dan rendah akan memunculkan gangguan fisiologis bagi genotipe ercis yang peka akibat meningkatnya suhu yang menyebabkan aborsi biji sehingga menurunkan hasil (Larmure dan Munier-Jolain, 2019).

Penyediaan varietas ercis adaptif dataran rendah harus dilakukan untuk memenuhi permintaan ercis di Indonesia. Pemuliaan tanaman ercis adaptif dataran rendah dapat dilakukan melalui pemanfaatan plasma nutfah ersil lokal yang sudah beradaptasi di Indonesia (Sari et al., 2019)

Pemuliaan tanaman ercis dari varietas lokal adaptif diarahkan untuk mendapatkan varietas unggul berdaya hasil tinggi dan adaptif di daerah dataran rendah melalui kegiatan seleksi. Seleksi dengan tujuan perbaikan karakter sangat ditentukan oleh keragaman genetik yang luas dengan heritabilitas tinggi, di mana keragaman genetik yang luas akan mempengaruhi keberhasilan seleksi (Handayani dan Hidayat, 2012; Jameela et al., 2014). Kegiatan seleksi akan berjalan efektif bila nilai kemajuan genetik tinggi dan ditunjang oleh nilai keragaman genetik dan nilai heritabilitas yang juga tinggi (Herawati $e t$ al., 2009).

Tujuan dari penelitian ini ialah untuk mengetahui keragaman karakter dan heritabilitas 82 genotipe ercis di dataran rendah, serta menentukan genotipe-genotipe ercis yang mempunyai hasil tinggi potensial untuk dikembangkan di dataran rendah. Hipotesis dari penelitian ini ialah terdapat karakter yang memiliki keragaman luas dan nilai heritabilitas tinggi, serta terdapat genotipe yang potensial dikembangkan di dataran rendah.

\section{Bahan dan Metode}

Penelitian dilaksanakan pada bulan Desember 2018 - April 2019 di Seed and Nursery Industry, Agro Techno Park, Universitas Brawijaya. Lokasi penelitian berada di Desa Jatikerto Kecamatan Kromengan, Kabupaten Malang, Jawa Timur, yang berada pada ketinggian $\pm 220-400 \mathrm{~m}$ dpl. Suhu minimum berkisar $24{ }^{\circ} \mathrm{C}$ dan suhu maksimum $31{ }^{\circ} \mathrm{C}$ dengan rata-rata curah hujan 101-543 mm per tahun.

Bahan genetik yang digunakan ialah 82 genotipe ercis hasil seleksi introduksi dan galur murni serta tiga pembanding (Tabel 1), pupuk kandang, NPK, ZA, dan pestisida. Alat yang digunakan yaitu alat budidaya, alat ukur (meteran, jangka sorong, timbangan analitik), ajir bambu, tali ajir, tray, papan dan kertas label, amplop cokelat, kamera, alat tulis dan Guidelines for The Conduct of Tests for Distinctness, Uniformity and Stability Pea (Pisum sativum L.) (UPOV, 2009).

Metode penelitian disusun berdasarkan percobaan secara augmented design. Bahan genetik disebar ke dalam enam blok. Setiap blok tidak terdapat genotipe yang sama. Pembanding diulang pada masing-masing blok, sehingga didapatkan total 100 plot penelitian. Setiap plot terdiri dari 8 tanaman dan diambil 4 tanaman untuk pengamatan polong kering. Plot percobaan berupa barisan tunggal sepanjang 0,8 $\mathrm{m}$ dengan jarak antar plot $80 \mathrm{~cm}$ dan jarak di dalam plot $10 \mathrm{~cm}$. Pengamatan dilakukan pada 32 karakter kuantitatif dan 22 karakter kualitatif.

Data kuantitatif dari genotipe uji dan pembanding dianalisis menggunakan analisis varians (ANOVA) untuk augmented design (Sharma, 2006) (Tabel 2). Apabila hasil F hitung berbeda nyata, uji least significant increase (LSI) dilakukan untuk menentukan genotipe yang mempunyai hasil lebih baik dibandingkan pembanding (Petersen, 1994): 
Tabel 1. Daftar genotipe ercis (P. sativum L.) yang digunakan

\begin{tabular}{clclclcl}
\hline No. & Kode Genotipe & No. & \multicolumn{1}{c}{ Kode Genotipe } & No. & Kode Genotipe & No. & Kode Genotipe \\
\hline 1 & $01(16)(2)-1$ & 22 & Batu-1-2 & 43 & GRT(PSO-3-1) & 64 & TMG1-4 \\
2 & $01(16)(3)-1$ & 23 & Batu-1-4 & 44 & GRT02(1)-1 & 65 & TMG2-1 \\
3 & $02(16)(2)$ & 24 & Batu-2 & 45 & GRT-02(2)-1 & 66 & TMG2-2 \\
4 & $03(16)(2)-1$ & 25 & Batu-3 & 46 & GRT-02(2)-2 & 67 & TMG2-3 \\
5 & $03(16)(2)-2$ & 26 & Bromo-1 & 47 & GRT04(1)-1 & 68 & TMG2-4 \\
6 & $03(16)(3)-1$ & 27 & Bromo-2 & 48 & GRT04(1)-2 & 69 & TMG3-1 \\
7 & $03-(16)-(3)-2$ & 28 & Bromo-3 & 49 & GRT04(3)-1 & 70 & TMG3-2 \\
8 & $03(16)(3)-3$ & 29 & Bromo-4 & 50 & GRT04(3)-2 & 71 & TMG4-1 \\
9 & $03-(16)-1$ & 30 & Bromo-5 & 51 & SMG(C)(1) & 72 & TMG4-2 \\
10 & $04(16)(1)$ U1 & 31 & Bromo-6 & 52 & SMG(C)(2) & 73 & TMG4-3 \\
11 & $04(16)(1)$ U2 & 32 & BTG-1 & 53 & SMG(C)(3)-1 & 74 & TMG5-1 \\
12 & $04(16)-5$ & 33 & BTG-2 & 54 & SMG(D)(3) & 75 & TMG5-2 \\
13 & $05(16)(2)-1$ & 34 & BTG-3 & 55 & SMG(E)(3)1 & 76 & TMG6-1 \\
14 & $05-(16)-1$ & 35 & BTG-4 & 56 & SMG(H)(03) & 77 & TMG6-2 \\
15 & $06-(16)-(11)-1$ & 36 & BTG-5 & 57 & SMG(H)(05) & 78 & TMG6-3 \\
16 & $06(16) 1-1$ & 37 & GRT-(03) & 58 & SMG(H)(05)-1 & 79 & TMG7-1 \\
17 & $06(16) 2-1$ & 38 & GRT(04)(1) & 59 & Taichung(C) & 80 & TMG7-2 \\
18 & $3(16) 1-2$ & 39 & GRT(PSO-1-1) & 60 & Taichung (H) & 81 & TMG8-1 \\
19 & $10-(16)-(1)$ & 40 & GRT(PSO-1-2) & 61 & TMG1-1 & 82 & TMG8-2 \\
20 & Batu-1 & 41 & GRT(PSO-2-1) & 62 & TMG1-2 & 83 & Calibra [CEK] \\
21 & Batu-1-1 & 42 & GRT(PSO-2-2) & 63 & TMG1-3 & 84 & SMG(H)(03) [CEK] \\
& & & & & & 85 & $05-(16)-1$ [CEK] \\
\hline
\end{tabular}

Keterangan: Introduksi: kode genotipe urutan no. 1-21; Taichung, Calibra, Batu (lokal Batu); BTG (lokal Berastagi); GRT (lokal Garut); TMG (lokal Temanggung); SMG (lokal Semarang); Bromo (lokal Bromo).

Tabel 2. Analisis varians untuk augmented design

\begin{tabular}{lllll}
\hline Sumber Variasi & $\mathrm{Db}$ & Jumlah Kuadrat & Kuadrat Tengah & F hitung \\
\hline Blok & $\mathrm{b}-1$ & $\mathrm{JKb}$ & $\mathrm{KTb}$ & $\mathrm{KTb} / \mathrm{KTE}$ \\
Perlakuan (entri) & $(\mathrm{c}+\mathrm{g})-1$ & $\mathrm{Jkp}$ & $\mathrm{KTp}$ & KTp/KTE \\
Cek & $\mathrm{c}-1$ & $\mathrm{JKc}$ & $\mathrm{KTc}$ & $\mathrm{KTc} /$ KTE \\
Genotipe & $\mathrm{g}-1$ & $\mathrm{JKg}$ & $\mathrm{KTg}$ & $\mathrm{KTg} / \mathrm{KTE}$ \\
Cek vs. Genotipe $(\mathrm{g})$ & 1 & $\mathrm{JKcg}$ & $\mathrm{KTcg}$ & $\mathrm{KTcg} / \mathrm{KTE}$ \\
Eror & $(\mathrm{c}-1)(\mathrm{b}-1)$ & $\mathrm{JKE}$ & $\mathrm{KTE}$ & - \\
Total & $(\mathrm{b} . \mathrm{c}+\mathrm{g})-1$ & $\mathrm{JKT}$ & & \\
\hline
\end{tabular}

Sumber: Sharma (2006)

$L S I=t_{\alpha} \sqrt{\frac{(b+1)(c+1) K T E}{b . c}}$

Keterangan:

$\mathrm{t}_{\alpha}=$ nilai tengah $t$-student pada a pada derajat bebas dari KTE pada satu arah (one-tailed)

$\mathrm{KTE}=$ kuadrat tengah eror (galat)

$\mathrm{c} \quad=$ jumlah cek

$\mathrm{b} \quad=$ jumlah blok

Pendugaan komponen varians genetik dan varians fenotipe dihitung dengan persamaan:

Var. lingkungan $\left(\sigma^{2}\right) \quad=K T E$

Var. fenotipe $\left(\sigma^{2} \mathrm{f}\right) \quad=\mathrm{KTg}$

Var. genetik $\left(\sigma^{2} g\right) \quad=\sigma_{f}^{2}-\sigma^{2}$
$=\mathrm{KTg}-\mathrm{KTE}$

Menurut Singh dan Chaudhary (1979), koefisien variasi genetik (KVG) dan koefisien variasi fenotipe (KVF) pada masing-masing karakter dihitung dengan persamaan:

$\mathrm{KVG}=\frac{\sqrt{\sigma^{2} \mathrm{~g}}}{\overline{\mathrm{x}}} \times 100 \%$

$\mathrm{KVF}=\frac{\sqrt{\sigma^{2} \mathrm{p}}}{\overline{\mathrm{x}}} \times 100 \%$

Keterangan:

$\mathrm{KVG}=$ koefisien variasi genetik

$\mathrm{KVF}=$ koefisien variasi fenotipe

$\sigma^{2} \mathrm{~g} \quad=$ varians genotipe

$\sigma^{2} p=$ varians fenotipe 
$\bar{x} \quad=$ rata-rata seluruh populasi tiap karakter tanaman

Kriteria KVG dan KVF menurut Singh dan Chaudhary (1979) yaitu rendah (KVG dan KVF $<10 \%)$, sedang $(10 \% \leq \mathrm{KVG}$ dan $\mathrm{KVF} \leq 25 \%)$ dan tinggi (KVG > 25\%).

Nilai duga heritabilitas dalam arti luas dihitung berdasarkan pemisahan komponen varians menggunakan persamaan (Acquaah, 2012):

$\mathrm{h}^{2}=\frac{\sigma_{\mathrm{g}}^{2}}{\sigma_{\mathrm{p}}^{2}}$

$h^{2}=\frac{\sigma_{\mathrm{g}}^{2}}{\sigma_{\mathrm{g}}^{2}+\sigma_{\mathrm{e}}^{2}}$

Keterangan:

$\sigma_{g}^{2} \quad=$ varians genetik $\sigma_{e}^{2} \quad=$ varians lingkungan

Kriteria nilai duga heritabilitas: tinggi (h2 > $0,50)$, sedang $(0,20 \leq \mathrm{h} 2 \leq 0,50)$ dan rendah $(\mathrm{h} 2<$ 0,20) (Stansfield, 1991)

\section{Hasil dan Pembahasan}

Hasil analisis varians menunjukkan perbedaan genotipe ercis yang digunakan memberikan pengaruh terhadap beberapa karakter yang diamati (Tabel 3). Hal ini menunjukkan bahwa keragaman yang terjadi pada masing-masing karakter disebabkan oleh pengaruh genotipe yang digunakan.

Tabel 3. Analisis varians karakter genotipe ercis (Pisum sativum L.) menggunakan metode augmented design di dataran rendah

\begin{tabular}{|c|c|c|c|c|c|c|}
\hline \multirow{2}{*}{ No. } & \multirow{2}{*}{ Karakter } & \multirow{2}{*}{$\begin{array}{l}\text { Rata- } \\
\text { Rata }\end{array}$} & \multicolumn{2}{|c|}{ Rentang } & \multirow{2}{*}{$\begin{array}{c}\text { Kuadrat Tengah } \\
\text { Genotipe }\end{array}$} & \multirow{2}{*}{ Eror } \\
\hline & & & Min & Maks & & \\
\hline 1 & Tinggi tanaman $(\mathrm{cm})$ & 164,26 & 96,20 & 244,35 & $1064,73^{* *}$ & 141,23 \\
\hline 2 & Jarak antar node $(\mathrm{cm})$ & 10,20 & 7,00 & 14,63 & $2,47^{* *}$ & 0,5 \\
\hline 3 & Jumlah cabang & 1,75 & 0,00 & 4,00 & 0,79 ns & 1,9 \\
\hline 4 & Jumlah maks. leaflets per tanaman & 34,61 & 17,50 & 83,25 & $134,37 \mathrm{~ns}$ & 152,82 \\
\hline 5 & Jumlah node fertil & 17,37 & 13,00 & 24,50 & 5,26ns & 3,45 \\
\hline 6 & Umur berbunga (HST) & 35,77 & 29,00 & 48,00 & $26,40^{*}$ & 7,19 \\
\hline 7 & Umur panen kering (HST) & 63,43 & 56,00 & 79,00 & $29,61^{*}$ & 7,39 \\
\hline 8 & Panjang stipula $(\mathrm{cm})$ & 4,95 & 3,25 & 6,85 & $0,53^{*}$ & 0,16 \\
\hline 9 & Lebar stipula $(\mathrm{cm})$ & 2,55 & 1,50 & 4,00 & $0,23^{*}$ & 0,07 \\
\hline 10 & Jarak aksil hingga ujung stipula (cm) & 3,73 & 2,35 & 4,87 & $0,28^{*}$ & 0,11 \\
\hline 11 & Jarak aksil hingga leaflets pertama $(\mathrm{cm})$ & 5,00 & 3,60 & 7,20 & $0,49^{*}$ & 0,16 \\
\hline 12 & Panjang leaflets $(\mathrm{cm})$ & 3,84 & 2,75 & 4,87 & $0,22 \mathrm{~ns}$ & 0,32 \\
\hline 13 & Lebar leaflets $(\mathrm{cm})$ & 2,20 & 1,50 & 3,25 & $0,14 \mathrm{~ns}$ & 0,06 \\
\hline 14 & Panjang tangkai hingga polong pertama $(\mathrm{cm})$ & 6,15 & 1,28 & 14,58 & $8,75 \mathrm{~ns}$ & 5,40 \\
\hline 15 & Jarak antar polong 1 dan $2(\mathrm{~cm})$ & 0,14 & 0,00 & 2,85 & $0,23 \mathrm{~ns}$ & 0,26 \\
\hline 16 & Jumlah braktea & 4,72 & 0,00 & 24,25 & $32,80 \mathrm{~ns}$ & 46,45 \\
\hline 17 & Bobot brangkasan daun (g) & 1,66 & 0,39 & 5,37 & $1,07^{* *}$ & 0,20 \\
\hline 18 & Bobot brangkasan akar (g) & 0,03 & 0,00 & 0,12 & $0,00 \mathrm{~ns}$ & 0,00 \\
\hline 19 & Bobot brangkasan batang $(\mathrm{g})$ & 2,22 & 0,54 & 7,16 & $2,12^{* *}$ & 0,19 \\
\hline 20 & Jumlah polong kering per tanaman & 8,26 & 2,25 & 17,25 & $9,88 \mathrm{~ns}$ & 7,48 \\
\hline 21 & Bobot polong kering per tanaman (g) & 6,16 & 1,94 & 14,69 & $5,51^{*}$ & 2,04 \\
\hline 22 & Bobot biji kering per tanaman $(\mathrm{g})$ & 5,39 & 1,68 & 13,43 & $4,29 *$ & 1,55 \\
\hline 23 & Jumlah biji kering per tanaman & 30,33 & 8,50 & 73,50 & $133,53 \mathrm{~ns}$ & 82,59 \\
\hline 24 & Bobot 100 biji kering $(\mathrm{g})$ & 17,86 & 13,43 & 24,55 & 4,43ns & 3,54 \\
\hline 25 & Bobot biji kering per polong $(\mathrm{g})$ & 0,81 & 0,50 & 1,44 & $0,03 * *$ & 0,00 \\
\hline 26 & Jumlah biji kering per polong & 4,36 & 3,00 & 6,00 & $0,44 \mathrm{~ns}$ & 0,33 \\
\hline 27 & Panjang polong kering $(\mathrm{cm})$ & 5,93 & 4,45 & 9,42 & $0,53^{*}$ & 0,18 \\
\hline 28 & Lebar polong kering $(\mathrm{mm})$ & 10,38 & 7,70 & 16,87 & $3,06^{* *}$ & 0,45 \\
\hline 29 & Tebal polong kering (mm) & 6,46 & 5,76 & 8,21 & $0,19 \mathrm{~ns}$ & 0,13 \\
\hline 30 & Panjang biji kering $(\mathrm{mm})$ & 7,48 & 6,60 & 8,13 & $0,10 \mathrm{~ns}$ & 0,04 \\
\hline 31 & Lebar biji kering $(\mathrm{mm})$ & 6,89 & 5,95 & 7,71 & $0,13 \mathrm{~ns}$ & 0,05 \\
\hline 32 & Tebal biji kering (mm) & 5,54 & 4,83 & 7,43 & $0,11 \mathrm{~ns}$ & 0,09 \\
\hline
\end{tabular}

Keterangan: * : berbeda nyata pada taraf nyata $5 \%$; ${ }^{* *}$ : berbeda nyata pada taraf nyata $1 \%$; ns : tidak berbeda nyata (non-significant) 
Keragaman genetik dan fenotipe. Keragaman karakter 82 genotipe ercis dilihat melalui keragaman karakter kuantitatif dan karakter kualitatif. Keragaman karakter kuantitatif ditentukan melalui nilai KVG dan KVF. Keragaman genetik, keragaman fenotipik, dan nilai duga heritabilitas merupakan beberapa parameter genetik yang dapat digunakan sebagai dasar pertimbangan agar kegiatan seleksi berjalan efektif dan efisien (Hapsari, 2014).

Tabel 4 menunjukkan hasil nilai KVG dan KVF 82 genotipe ercis yang ditanam di dataran rendah memiliki nilai yang bervariasi. Karakter dengan nilai KVG dan KVF dengan kriteria tinggi didapatkan pada karakter panjang tangkai hingga polong pertama, jumlah braktea, bobot brangkasan daun, bobot brangkasan batang, bobot polong kering per tanaman, dan bobot biji kering per tanaman. Jhanavi et al. (2018) menjelaskan bahwa nilai KVG dan KVF yang tinggi menunjukkan adanya variabilitas yang cukup pada sumberdaya genetik yang digunakan dan sifat tersebut diatur oleh gen aditif. Hal ini menunjukkan bahwa terdapat banyak peluang untuk meningkatkan karakter tersebut melalui seleksi secara langsung.

Hasil penelitian menunjukkan hasil bahwa nilai KVF cenderung lebih besar dibandingkan nilai KVG, hal ini menandakan keragaman yang muncul lebih banyak dipengaruhi oleh faktor lingkungan. Hasil penelitian serupa ditemukan oleh Ton et al. (2018); Jaiswal et al. (2013); Saxesena et al. (2014); dan Katoch et al. (2016) yang menunjukkan hasil nilai KVF secara umum lebih tinggi dibandingkan nilai KVG karena variasi oleh lingkungan lebih dominan dibandingkan variasi faktor genetik.

Tabel 4. Nilai koefisien variasi genetik (KVG) dan koefisien variasi fenotipe (KVF) pada karakter ercis (Pisum sativum L.) di dataran rendah

\begin{tabular}{clcccc}
\hline No. & \multicolumn{1}{c}{ Karakter } & KVG & Kriteria & KVF & Kriteria \\
\hline 1 & Tinggi tanaman $(\mathrm{cm})$ & 21,15 & Sedang & 22,71 & Sedang \\
2 & Jarak antar node $(\mathrm{cm})$ & 15,87 & Sedang & 17,76 & Sedang \\
3 & Jumlah cabang per tanaman & 23,94 & Sedang & 20,40 & Sedang \\
4 & Jumlah maksimum leaflets per tanaman & 12,03 & Sedang & 32,47 & Tinggi \\
5 & Jumlah node termasuk node yang fertil & 7,56 & Rendah & 12,90 & Sedang \\
6 & Umur berbunga (HST) & 12,17 & Sedang & 14,26 & Sedang \\
7 & Umur panen kering (HST) & 7,35 & Rendah & 8,48 & Rendah \\
8 & Panjang stipula $(\mathrm{cm})$ & 13,53 & Sedang & 16,14 & Sedang \\
9 & Lebar stipula $(\mathrm{cm})$ & 17,49 & Sedang & 20,94 & Sedang \\
10 & Jarak aksil hingga ujung stipula $(\mathrm{cm})$ & 12,37 & Sedang & 15,72 & Sedang \\
11 & Panjang aksil hingga leaflets pertama & 12,31 & Sedang & 15,12 & Sedang \\
12 & Panjang leaflets $(\mathrm{cm})$ & 8,81 & Rendah & 12,72 & Sedang \\
13 & Lebar leaflets (cm) & 14,85 & Sedang & 19,44 & Sedang \\
14 & Panjang tangkai tingga polong pertama $(\mathrm{cm})$ & 30,00 & Tinggi & 48,51 & Tinggi \\
15 & Jarak antara polong 1 dan polong 2 $(\mathrm{cm})$ & 12,39 & Sedang & 23,28 & Sedang \\
16 & Jumlah braktea & 25,33 & Tinggi & 51,64 & Tinggi \\
17 & Bobot brangkasan: daun $(\mathrm{g})$ & 60,65 & Tinggi & 67,40 & Tinggi \\
18 & Bobot brangkasan: akar $(\mathrm{g})$ & 1,57 & Rendah & 2,50 & Rendah \\
19 & Bobot brangkasan: batang $(\mathrm{g})$ & 71,33 & Tinggi & 74,76 & Tinggi \\
20 & Jumlah polong per tanaman & 18,26 & Sedang & 37,06 & Tinggi \\
21 & Bobot polong per tanaman $(\mathrm{g})$ & 33,07 & Tinggi & 41,64 & Tinggi \\
22 & Bobot biji per tanaman $(\mathrm{g})$ & 33,76 & Tinggi & 42,25 & Tinggi \\
23 & Jumlah biji per tanaman & 23,53 & Sedang & 38,10 & Tinggi \\
24 & Berat 100 benih $(\mathrm{g})$ & 5,92 & Rendah & 13,21 & Sedang \\
25 & Bobot biji per polong $(\mathrm{g})$ & 22,17 & Sedang & 24,18 & Sedang \\
26 & Jumlah biji per polong & 8,04 & Rendah & 16,10 & Sedang \\
\hline & & & & & \\
& & &
\end{tabular}


Tabel 4. Nilai koefisien variasi genetik (KVG) dan koefisien variasi fenotipe (KVF) pada karakter ercis (Pisum sativum L.) di dataran rendah

\begin{tabular}{clcccc}
\hline No. & \multicolumn{1}{c}{ Karakter } & KVG & Kriteria & KVF & Kriteria \\
\hline 27 & Panjang polong $(\mathrm{cm})$ & 10,44 & Sedang & 12,78 & Sedang \\
28 & Lebar polong $(\mathrm{mm})$ & 16,41 & Sedang & 17,78 & Sedang \\
29 & Tebal polong $(\mathrm{mm})$ & 4,00 & Rendah & 7,10 & Rendah \\
30 & Panjang biji $(\mathrm{mm})$ & 3,38 & Rendah & 4,42 & Rendah \\
31 & Lebar biji $(\mathrm{mm})$ & 4,11 & Rendah & 5,30 & Rendah \\
32 & Tebal biji $(\mathrm{mm})$ & 2,93 & Rendah & 6,16 & Rendah \\
\hline
\end{tabular}

Keterangan: KVG: koefisien variasi genetik, KVF: koefisien variasi fenotipe. Kriteria KVG dan KVF: tinggi $(>25 \%)$, sedang $(10 \% \leq$ KVG dan KVF $\leq 25 \%)$ dan rendah (KVG $<10 \%)$.

Tabel 5. Penampilan karakter kualitatif 82 genotipe ercis (Pisum sativum L.) di dataran rendah

\begin{tabular}{|c|c|c|c|c|c|c|c|}
\hline No & $\begin{array}{l}\text { Karakter } \\
\text { Kualitatif }\end{array}$ & Kategori & $\begin{array}{c}\% \\
\text { Genotipe }\end{array}$ & No & $\begin{array}{l}\text { Karakter } \\
\text { Kualitatif }\end{array}$ & Kategori & $\begin{array}{c}\% \\
\text { Genotipe }\end{array}$ \\
\hline \multirow[t]{2}{*}{1.} & WAt & Tidak ada & 13,41 & 12. & WD & Hijau kekuningan & 6,10 \\
\hline & & Ada & 86,59 & & & Hijau & 93,90 \\
\hline \multirow[t]{3}{*}{2.} & WAa & Tidak ada & 13,41 & 13. & IWD & Terang & 9,09 \\
\hline & & Cincin tunggal & 64,63 & & & Sedang & 67,53 \\
\hline & & Cincin ganda & 21,95 & & & Gelap & 23,38 \\
\hline 3. & KL & Ada & 100 & 14. & $\mathrm{BD}$ & Ada & 100 \\
\hline 4. & WW & Ungu kemerahan & 100 & 15 & WS & Putih & 100 \\
\hline \multirow[t]{3}{*}{5.} & BS & Sangat cembung & 4,88 & 16 & BA & Mengakumulasi & 43,90 \\
\hline & & Agak cembung & 28,05 & & & Akut & 45,12 \\
\hline & & Datar & 67,07 & & & Bulat & 10,98 \\
\hline \multirow[t]{4}{*}{6.} & $\mathrm{DD}$ & $\begin{array}{l}\text { Tidak ada/sangat } \\
\text { lemah }\end{array}$ & 9,76 & 17. & PP & $\begin{array}{l}\text { Tidak } \\
\text { ada/sebagian }\end{array}$ & 81,71 \\
\hline & & Lemah & 24,39 & & & Seluruh & 18,29 \\
\hline & & Sedang & 41,46 & 18. & KD & Tidak ada & 89,02 \\
\hline & & Kuat & 24,39 & & & Ada & 10,98 \\
\hline \multirow[t]{3}{*}{7.} & KB & Jarang & 46,55 & 19. & LP & $\begin{array}{l}\text { Tidak ada/sangat } \\
\text { lemah }\end{array}$ & 41,46 \\
\hline & & Sedang & 53,45 & & & Lemah & 46,34 \\
\hline & & Padat & 41,38 & & & Sedang & 12,20 \\
\hline \multirow[t]{2}{*}{8.} & BP & Runcing & 56,10 & 20. & BB & Elips & 26,83 \\
\hline & & Tumpul & 43,90 & & & Silinder & 73,17 \\
\hline \multirow[t]{2}{*}{9.} & WK & Kuning & 92,68 & 21. & WT & $\begin{array}{l}\text { Cokelat } \\
\text { kemerahan }\end{array}$ & 28,05 \\
\hline & & Oranye & 7,32 & & & Cokelat & 50,00 \\
\hline 10. & WP & Hijau & 100 & & & Hijau kecokelatan & 21,95 \\
\hline 11. & WH & $\begin{array}{l}\text { Sama dengan } \\
\text { testa } \\
\text { Lebih gelap dari } \\
\text { testa }\end{array}$ & $\begin{array}{l}75,61 \\
24,39\end{array}$ & 22. & ТВ & Ada & 100 \\
\hline
\end{tabular}

Keterangan: WAt: warna antosisanin tanaman; WAa: warna antosianin aksil; KL: keberadaan leaflets; WW: warna wing bunga; BS: bentuk standar bunga; DD: dentation daun; KB: kerapatan bercak daun; BP: bentuk ujung polong; WK: warna kotiledon biji; WP: warna polong; WH: warna hilum biji; WD: warna daun; IWD: intensitas warna daun; BD: bercak daun; WS: warna standar bunga; BA: bentuk apex; PP: perkamen polong; KD: ketebalan dinding polong; LP: lengkungan polong; BB: bentuk biji; WT: warna testa biji; TB: Tekstur biji. Karakter yang ditampilkan hanya karakter yang muncul pada pengamatan berdasarkan deskriptor UPOV (2009) untuk Pisum sativum L. 
Karakter kualitatif yang diamati pada penelitian menunjukkan bahwa terdapat 6 karakter yang memiliki keseragaman antar genotipe dan 16 karakter lainnya yang beragam antar genotipe (Tabel 5). Syukur et al. (2011) menjelaskan bahwa karakter kualitatif lebih banyak dikendalikan oleh gen sederhana (satu atau dua gen) dan tidak atau sedikit dipengaruhi oleh lingkungan. Penampilan karakter kualitatif 82 genotipe ercis lebih banyak dipengaruhi oleh faktor genetik dan dapat diturunkan pada keturunannya.

Nilai duga heritabilitas. Nilai duga heritabilitas 82 genotipe ercis di dataran rendah ditampilkan pada Tabel 6. Hasil penelitian menunjukkan bahwa terdapat beberapa karakter yang memiliki nilai heritabilitas dengan kriteria tinggi.

Tabel 6. Nilai duga heritabilitas 82 genotipe ercis (Pisum sativum L.) di dataran rendah

\begin{tabular}{|c|c|c|c|c|c|c|}
\hline No. & Karakter & $\mathrm{O}_{\mathrm{e}}^{2}$ & $\sigma^{2} g$ & $\sigma_{\mathrm{f}}^{2}$ & $\mathrm{~h}^{2}$ & Kriteria \\
\hline 1 & Tinggi tanaman $(\mathrm{cm})$ & 141,23 & 923,51 & 1064,73 & 0,87 & Tinggi \\
\hline 2 & Jarak antar node $(\mathrm{cm})$ & 0,50 & 1,97 & 2,47 & 0,80 & Tinggi \\
\hline 3 & Jumlah cabang per tanaman & 0,23 & $-0,13$ & 0,10 & $-1,38$ & Rendah \\
\hline 4 & Jumlah maksimum leaflets per tanaman & 152,82 & $-18,45$ & 134,37 & $-0,14$ & Rendah \\
\hline 5 & Jumlah node termasuk node yang fertil & 3,45 & 1,81 & 5,26 & 0,34 & Sedang \\
\hline 6 & Umur berbunga (HST) & 7,19 & 19,21 & 26,40 & 0,73 & Tinggi \\
\hline 7 & Umur panen kering (HST) & 7,39 & 22,22 & 29,61 & 0,75 & Tinggi \\
\hline 8 & Panjang stipula $(\mathrm{cm})$ & 0,16 & 0,38 & 0,53 & 0,70 & Tinggi \\
\hline 9 & Lebar stipula (cm) & 0,07 & 0,16 & 0,23 & 0,70 & Tinggi \\
\hline 10 & Jarak aksil hingga ujung stipula $(\mathrm{cm})$ & 0,11 & 0,18 & 0,28 & 0,62 & Tinggi \\
\hline 11 & Panjang aksil hingga leaflets pertama & 0,16 & 0,32 & 0,49 & 0,66 & Tinggi \\
\hline 12 & Panjang leaflets $(\mathrm{cm})$ & 0,32 & $-0,10$ & 0,22 & $-0,48$ & Rendah \\
\hline 13 & Lebar leaflets $(\mathrm{cm})$ & 0,06 & 0,08 & 0,14 & 0,58 & Tinggi \\
\hline 14 & $\begin{array}{l}\text { Panjang tangkai tingga polong pertama } \\
(\mathrm{cm})\end{array}$ & 5,40 & 3,35 & 8,75 & 0,38 & Sedang \\
\hline 15 & Jarak antara polong 1 dan polong $2(\mathrm{~cm})$ & 0,06 & $-0,01$ & 0,04 & $-0,28$ & Rendah \\
\hline 16 & Jumlah braktea & 1,00 & 0,32 & 1,33 & 0,24 & Sedang \\
\hline 17 & Bobot brangkasan: daun (g) & 0,20 & 0,86 & 1,07 & 0,81 & Tinggi \\
\hline 18 & Bobot brangkasan: akar (g) & 0,00 & 0,00 & 0,00 & 0,40 & Sedang \\
\hline 19 & Bobot brangkasan: batang $(\mathrm{g})$ & 0,19 & 1,93 & 2,12 & 0,91 & Tinggi \\
\hline 20 & Jumlah polong per tanaman & 7,48 & 2,40 & 9,88 & 0,24 & Sedang \\
\hline 21 & Bobot polong per tanaman (g) & 2,04 & 3,48 & 5,51 & 0,63 & Tinggi \\
\hline 22 & Bobot biji kering per tanaman (g) & 1,55 & 2,74 & 4,29 & 0,64 & Tinggi \\
\hline 23 & Jumlah biji kering per tanaman & 82,59 & 50,94 & 133,53 & 0,38 & Sedang \\
\hline 24 & Bobot 100 biji (g) & 3,54 & 0,89 & 4,43 & 0,20 & Sedang \\
\hline 25 & Bobot biji kering per polong (g) & 0,00 & 0,02 & 0,03 & 0,84 & Tinggi \\
\hline 26 & Jumlah biji kering per polong & 0,33 & 0,11 & 0,44 & 0,25 & Sedang \\
\hline 27 & Panjang polong $(\mathrm{cm})$ & 0,18 & 0,35 & 0,53 & 0,67 & Tinggi \\
\hline 28 & Lebar polong (mm) & 0,45 & 2,61 & 3,06 & 0,85 & Tinggi \\
\hline 29 & Tebal polong $(\mathrm{mm})$ & 0,13 & 0,06 & 0,19 & 0,32 & Sedang \\
\hline 30 & Panjang biji kering (mm) & 0,04 & 0,06 & 0,10 & 0,58 & Tinggi \\
\hline 31 & Lebar biji kering $(\mathrm{mm})$ & 0,05 & 0,08 & 0,13 & 0,60 & Tinggi \\
\hline 32 & Tebal biji kering $(\mathrm{mm})$ & 0,09 & 0,02 & 0,11 & 0,23 & Sedang \\
\hline
\end{tabular}

Keterangan: $\quad \sigma_{\mathrm{e}}^{2}$ : ragam lingkungan, $\sigma^{2} \mathrm{~g}$ : ragam genetik, $\sigma_{\mathrm{f}}^{2}$ : ragam fenotipe, $\mathrm{h}^{2}$ : heritabilitas. Kriteria nilai duga heritabilitas: tinggi $\left(h^{2}>0,50\right)$, sedang $\left(0,20 \leq h^{2} \leq 0,50\right)$ dan rendah $\left(h^{2}<0,20\right)$. 
Heritabilitas merupakan suatu besaran yang menunjukkan proporsi faktor genetik terhadap faktor lingkungan yang ditampilkan suatu karakter. Heritabilitas ialah parameter genetik yang menggambarkan kemampuan suatu genotipe dalam populasi untuk mewariskan karakter-karakter yang dimiliki kepada keturunannya. Keragaman suatu karakter yang disebabkan oleh faktor genetik dapat diketahui melalui perhitungan heritabilitas (Sa'diyah et al., 2013). Karakter-karakter yang memiliki nilai duga heritabilitas dengan kriteria tinggi di antaranya ialah karakter tinggi tanaman, jarak antar node, umur berbunga, umur panen kering, panjang stipula, lebar stipula, jarak aksil hingga ujung stipula, panjang aksil hingga leaflets pertama, lebar leaflets, bobot brangkasan daun, bobot brangkasan batang, bobot polong kering per tanaman, bobot biji kering per tanaman, bobot biji kering per polong, panjang polong kering, lebar polong kering, panjang biji kering serta lebar biji kering.

Nilai heritabilitas yang tinggi menunjukkan bahwa penampilan suatu karakter banyak dipengaruhi oleh faktor genetik dibandingkan faktor lingkungan (Syukur et al., 2011). Barcchiya et al. (2018) menjelaskan bahwa nilai heritabilitas dalam arti luas akan membantu dalam kegiatan identifikasi karakter yang sesuai untuk seleksi dan membantu pemulia untuk memilih genotipe unggul berdasarkan penampilan fenotipik sifatsifat kuantitatif. Pemilihan genotipe untuk tujuan seleksi akan lebih baik apabila dilakukan berdasarkan nilai KVG yang tinggi bersamasama dengan nilai heritabilitas dan kemajuan genetik yang tinggi (Selvaraj et al., 2011).

Hasil penelitian menunjukkan beberapa karakter memiliki heritabilitas yang bernilai negatif. Nilai heritabilitas didapatkan dari perbandingan nilai varians genetik dengan varians fenotipe, sedangkan nilai varians genetik diperoleh dari operasi pengurangan varians fenotipe dengan varians lingkungan. Secara teori, nilai varians genetik tidak bisa bernilai negatif, namun secara lapang dapat bernilai negatif karena operasi penjumlahan dan pengurangan komponen varians sehingga diperoleh nilai negatif. Nilai varians lingkungan yang lebih besar dibandingkan varians fenotipe menyebabkan hasil varians genetik bernilai negatif. Hasil analisis varians pada karakter yang memiliki nilai heritabilitas negatif memiliki hasil tidak berbeda nyata (non-significant), sehingga dianggap tidak terjadi keragaman atau bernilai 0 (nol).

Genotipe terseleksi. Seleksi genotipe ercis dilakukan untuk mencari genotipe yang berpotensi dikembangkan di dataran rendah. Seleksi dilakukan pada karakter yang memiliki hasil analisis varians berbeda nyata dan memengaruhi karakter hasil, yaitu pada karakter umur berbunga, umur panen kering, bobot polong kering per tanaman, bobot biji kering per tanaman, dan bobot biji kering per polong. Genotipe yang terpilih ialah genotipe yang memiliki nilai rata-rata lebih besar dibandingkan rata-rata pembanding tambah nilai LSI, kecuali pada karakter umur berbunga dan umur panen kering. Pada kedua karakter ini, genotipe yang terseleksi ialah genotipe yang memiliki rata-rata lebih kecil dibandingkan ratarata pembanding dikurangi nilai LSI. Seleksi kemudian didasarkan pada skoring pada masing-masing karakter. Karakter yang memiliki beda nyata terbaik dibanding pembanding memiliki nilai skor paling tinggi. Genotipe yang terseleksi ialah genotipe yang memiliki total skor paling tinggi. Genotipe terpilih memiliki beda nyata paling banyak dibandingkan cek (pembanding).

Tabel 7. Tabulasi hasil seleksi 82 genotipe ercis berdasarkan karakter hasil.

\begin{tabular}{clccccc}
\hline \multirow{2}{*}{ No. } & \multirow{2}{*}{ Genotipe } & UB (HST) & UPK (HST) & BPT (g) & BBT (g) & BBP $(\mathrm{g})$ \\
\cline { 2 - 6 } & & $32,28 \mathrm{a}$ & $59,94 \mathrm{a}$ & $6,28 \mathrm{a}$ & $5,54 \mathrm{a}$ & $0,76 \mathrm{a}$ \\
1 & $01(16)(2)-1$ & 40,61 & $65,28 \mathrm{a}$ & $6,67 \mathrm{a}$ & $5,67 \mathrm{a}$ & $0,75 \mathrm{a}$ \\
2 & $01(16)(3)-1$ & 41,61 & 78,94 & 3,23 & 2,79 & $0,75 \mathrm{a}$ \\
3 & $02(16)(2)$ & 45,28 & 68,94 & $14,99 \mathrm{abc}$ & $13,64 \mathrm{abc}$ & $1,13 \mathrm{abc}$ \\
4 & $03(16)(2)-1$ & 38,61 & 68,61 & $5,1 \mathrm{a}$ & $4,47 \mathrm{a}$ & $0,76 \mathrm{a}$ \\
5 & $03(16)(2)-2$ & $37,61 \mathrm{a}$ & $62,61 \mathrm{a}$ & $6,17 \mathrm{a}$ & $5,55 \mathrm{a}$ & $0,78 \mathrm{a}$ \\
6 & $03(16)(3)-1$ & $32,61 \mathrm{a}$ & $58,61 \mathrm{a}$ & $7,93 \mathrm{a}$ & $7,14 \mathrm{a}$ & $0,92 \mathrm{ab}$ \\
7 & $03-(16)-(3)-2$ & $32,61 \mathrm{a}$ & $58,94 \mathrm{a}$ & 2,72 & 2,48 & $0,61 \mathrm{a}$ \\
8 & $03(16)(3)-3$ & $36,61 \mathrm{a}$ & $66,61 \mathrm{a}$ & $8,46 \mathrm{a}$ & $7,65 \mathrm{a}$ & $0,93 \mathrm{ab}$ \\
9 & $03-(16)-1$ & 43,28 & 75,94 & $5,88 \mathrm{a}$ & $4,97 \mathrm{a}$ & $0,62 \mathrm{a}$ \\
10 & $04(16)(1) \mathrm{U} 1$ & & & & \\
\hline
\end{tabular}


Tabel 7. Tabulasi hasil seleksi 82 genotipe ercis berdasarkan karakter hasil (lanjutan).

\begin{tabular}{|c|c|c|c|c|c|c|}
\hline \multirow{2}{*}{ No. } & \multirow{2}{*}{ Genotipe } & \multicolumn{5}{|c|}{ Karakter } \\
\hline & & UB (HST) & UPK (HST) & BPT (g) & BBT (g) & $\mathrm{BBP}(\mathrm{g})$ \\
\hline 11 & 04(16)(1)U2 & 42,28 & 67,94 & $7,57 a$ & $6,63 a$ & $0,83 a$ \\
\hline 12 & $04(16)-5$ & 47,28 & 68,61 & 2,63 & 2,31 & $0,74 \mathrm{a}$ \\
\hline 13 & $05(16)(2)-1$ & $33,28 \mathrm{a}$ & $62,94 a$ & $8,33 a$ & $7,5 \mathrm{a}$ & $0,92 \mathrm{ab}$ \\
\hline 14 & $05-(16)-1$ & $32,28 \mathrm{a}$ & $60,61 \mathrm{a}$ & 2,04 & 2,05 & $0,66 a$ \\
\hline 15 & $06-(16)-(11)-1$ & $34,28 \mathrm{a}$ & $66,61 a$ & $7,42 a$ & $6,6 a$ & $0,9 \mathrm{ab}$ \\
\hline 16 & $06(16) 1-1$ & $29,28 \mathrm{ab}$ & $59,61 \mathrm{a}$ & $5,3 a$ & $4,97 \mathrm{a}$ & $0,78 \mathrm{a}$ \\
\hline 17 & $06(16) 2-1$ & $29,61 \mathrm{ab}$ & $57,94 a$ & 0,15 & 0,18 & $0,56 a$ \\
\hline 18 & 10-(16)-(1) & $36,28 \mathrm{a}$ & $59,61 \mathrm{a}$ & $5,5 \mathrm{a}$ & $5,01 \mathrm{a}$ & $0,61 \mathrm{a}$ \\
\hline 19 & $3(16) 1-2$ & $36,61 a$ & $63,61 \mathrm{a}$ & $9,41 \mathrm{ab}$ & $8,42 \mathrm{ab}$ & $0,99 \mathrm{abc}$ \\
\hline 20 & Batu 1 & 43,61 & 69,94 & 2,04 & 1,8 & $0,68 \mathrm{a}$ \\
\hline 21 & Batu 1-1 & 45,28 & 69,61 & $11,46 a b c$ & $9,9 \mathrm{abc}$ & $1,02 \mathrm{abc}$ \\
\hline 22 & Batu 1-2 & 43,28 & 68,61 & $9,04 a$ & $7,98 \mathrm{a}$ & $0,91 \mathrm{ab}$ \\
\hline 23 & Batu 1-4 & 45,61 & 78,94 & $5,95 a$ & $4,94 \mathrm{a}$ & $0,64 a$ \\
\hline 24 & Batu 2 & 46,28 & 69,94 & $11,07 \mathrm{abc}$ & $9,6 \mathrm{abc}$ & $1,08 \mathrm{abc}$ \\
\hline 25 & Batu 3 & 47,28 & 69,94 & 4,63 & 3,95 & $0,81 \mathrm{a}$ \\
\hline 26 & Bromo 1 & 39,28 & 69,61 & $5,76 a$ & $4,66 a$ & $0,75 a$ \\
\hline 27 & Bromo 2 & 42,28 & $66,94 a$ & $5,3 a$ & 3,94 & $0,59 a$ \\
\hline 28 & Bromo 3 & 40,28 & 67,94 & $6,8 \mathrm{a}$ & $5,48 \mathrm{a}$ & $0,9 \mathrm{ab}$ \\
\hline 29 & Bromo 4 & 43,61 & 68,61 & $8,95 a$ & $6,89 a$ & $1,3 \mathrm{abc}$ \\
\hline 30 & Bromo 5 & 43,61 & 68,94 & 4,3 & 3,56 & $1,36 a b c$ \\
\hline 31 & Bromo 6 & 38,61 & $62,94 a$ & $6,15 a$ & $4,82 \mathrm{a}$ & $0,81 \mathrm{a}$ \\
\hline 32 & BTG-1 & $37,61 \mathrm{a}$ & $65,94 a$ & 2,56 & 2,07 & $0,53 a$ \\
\hline 33 & BTG-2 & $32,28 \mathrm{a}$ & $62,94 a$ & $7,86 a$ & $6,77 a$ & $0,76 a$ \\
\hline 34 & BTG-3 & 38,28 & 68,61 & 4,9 & $4,25 a$ & $0,64 a$ \\
\hline 35 & BTG-4 & $37,28 \mathrm{a}$ & 68,61 & $5,94 a$ & $5,25 a$ & $0,76 a$ \\
\hline 36 & BTG-5 & $34,61 a$ & $63,94 a$ & $9,43 a b$ & $7,9 a$ & $1,13 \mathrm{abc}$ \\
\hline 37 & GRT-(03) & $30,61 \mathrm{a}$ & $62,61 \mathrm{a}$ & $6,4 a$ & $5,53 a$ & $0,89 \mathrm{ab}$ \\
\hline 38 & GRT(04)(1) & $30,61 a$ & $58,61 \mathrm{a}$ & $7,67 a$ & $6,49 a$ & $0,84 \mathrm{a}$ \\
\hline 39 & GRT(PSO-1-1) & $32,61 a$ & $60,61 a$ & $8,48 a$ & $7,17 \mathrm{a}$ & $0,72 a$ \\
\hline 40 & GRT(PSO-1-2) & $33,61 \mathrm{a}$ & $63,61 \mathrm{a}$ & $6,7 a$ & $5,76 a$ & $0,72 a$ \\
\hline 41 & GRT(PSO-2-1) & $36,28 \mathrm{a}$ & $62,61 a$ & $5,73 a$ & $5 a$ & $0,74 a$ \\
\hline 42 & GRT(PSO-2-2) & $35,61 a$ & $64,28 \mathrm{a}$ & $9,18 \mathrm{a}$ & $8,23 \mathrm{ab}$ & $0,88 \mathrm{ab}$ \\
\hline 43 & GRT(PSO-3-1) & $33,28 \mathrm{a}$ & $57,94 a$ & 2,61 & 2,28 & $1,46 a b c$ \\
\hline 44 & GRT 02(1)-1 & $28,61 \mathrm{ab}$ & $55,94 \mathrm{ab}$ & 4,83 & 4,05 & $0,87 a b$ \\
\hline 45 & GRT-02(2)-1 & $31,61 \mathrm{a}$ & $55,94 \mathrm{ab}$ & 2,21 & 1,73 & $0,74 \mathrm{a}$ \\
\hline 46 & GRT-02(2)-2 & $28,61 \mathrm{ab}$ & $55,94 \mathrm{ab}$ & 4,51 & 3,66 & $0,86 a b$ \\
\hline 47 & GRT04(1)-1 & $32,28 \mathrm{a}$ & $61,94 a$ & 4,4 & 3,66 & $0,9 \mathrm{ab}$ \\
\hline 48 & GRT04(1)-2 & $30,61 a$ & $56,28 \mathrm{ab}$ & $6,51 a$ & $5,47 \mathrm{a}$ & $0,78 \mathrm{a}$ \\
\hline 49 & GRT04(3)-1 & $30,28 a$ & $56,94 \mathrm{ab}$ & 3,66 & 3,04 & $0,92 \mathrm{ab}$ \\
\hline 50 & GRT04(3)-2 & $35,28 a$ & $64,61 a$ & $7,01 \mathrm{a}$ & $6,23 a$ & $1,01 \mathrm{abc}$ \\
\hline 51 & $\operatorname{SMG}(\mathrm{C})(1)$ & $32,28 \mathrm{a}$ & $59,94 a$ & $7,21 a$ & $6,59 a$ & $0,73 a$ \\
\hline 52 & $\operatorname{SMG}(\mathrm{C})(2)$ & $35,28 \mathrm{a}$ & $64,61 a$ & 4,75 & $4,35 a$ & $0,87 \mathrm{ab}$ \\
\hline 53 & SMG(C)(3)-1 & $33,28 \mathrm{a}$ & $57,94 a$ & 4,19 & 3,79 & $0,71 \mathrm{a}$ \\
\hline 54 & SMG(D)(3) & $34,28 \mathrm{a}$ & $59,61 \mathrm{a}$ & $6,12 a$ & $5,62 a$ & $0,87 \mathrm{ab}$ \\
\hline 55 & SMG(E)(3)1 & $31,28 \mathrm{a}$ & $57,94 a$ & 4,24 & 3,68 & $0,6 a$ \\
\hline 56 & SMG $(\mathrm{H})(03)$ & $33,61 \mathrm{a}$ & $62,94 a$ & $6,76 a$ & $6,06 a$ & $0,77 a$ \\
\hline 57 & SMG(H)(05) & $34,61 a$ & $58,94 a$ & 1,53 & 1,49 & $0,65 a$ \\
\hline 58 & SMG(H)(05)-1 & $31,61 a$ & $56,94 \mathrm{ab}$ & 2,33 & 2,19 & $0,7 \mathrm{a}$ \\
\hline 59 & Taichung (C) & 44,61 & 69,94 & $5,69 a$ & $5,04 a$ & $0,92 \mathrm{ab}$ \\
\hline 60 & Taichung (H) & 41,61 & 67,94 & $8,86 a$ & $7,82 \mathrm{a}$ & $0,81 \mathrm{a}$ \\
\hline 61 & TMG 1-1 & $33,61 a$ & $63,94 a$ & 0,59 & 0,65 & $0,45 a$ \\
\hline 62 & TMG 1-2 & $35,28 a$ & 68,94 & $7,56 a$ & $6,87 a$ & $0,81 a$ \\
\hline 63 & TMG 1-3 & $33,28 \mathrm{a}$ & $57,94 a$ & $8,84 a$ & $8,03 a$ & $0,86 a$ \\
\hline 64 & TMG 1-4 & $29,28 \mathrm{ab}$ & $56,94 \mathrm{ab}$ & 4,79 & $4,34 \mathrm{a}$ & $0,78 \mathrm{a}$ \\
\hline
\end{tabular}


Tabel 7. Tabulasi hasil seleksi 82 genotipe ercis berdasarkan karakter hasil (lanjutan).

\begin{tabular}{|c|c|c|c|c|c|c|c|}
\hline \multirow{2}{*}{ No. } & \multirow{2}{*}{\multicolumn{2}{|c|}{ Genotipe }} & \multicolumn{5}{|c|}{ Karakter } \\
\hline & & & UB (HST) & UPK (HST) & BPT (g) & BBT (g) & $\mathrm{BBP}(\mathrm{g})$ \\
\hline 65 & \multicolumn{2}{|c|}{ TMG 2-1 } & $33,28 \mathrm{a}$ & $56,94 \mathrm{ab}$ & $8,17 \mathrm{a}$ & $7,48 \mathrm{a}$ & $0,81 \mathrm{a}$ \\
\hline 66 & \multicolumn{2}{|c|}{ TMG 2-2 } & $36,61 \mathrm{a}$ & 70,61 & 3,36 & 2,98 & $0,64 a$ \\
\hline 67 & \multicolumn{2}{|c|}{ TMG 2-3 } & $35,61 a$ & $60,28 a$ & $8,77 a$ & $7,87 a$ & $0,82 \mathrm{a}$ \\
\hline 68 & \multicolumn{2}{|c|}{ TMG 2-4 } & 39,61 & $63,28 a$ & $5,28 \mathrm{a}$ & $4,46 a$ & $0,55 a$ \\
\hline 69 & \multicolumn{2}{|c|}{ TMG 3-1 } & $36,28 \mathrm{a}$ & $59,61 a$ & 3,56 & 3,31 & $0,79 a$ \\
\hline 70 & \multicolumn{2}{|c|}{ TMG 3-2 } & $30,61 a$ & $54,61 \mathrm{ab}$ & 4,98 & $4,41 \mathrm{a}$ & $0,61 \mathrm{a}$ \\
\hline 71 & \multicolumn{2}{|c|}{ TMG 4-1 } & $31,61 \mathrm{a}$ & $56,61 \mathrm{ab}$ & $8,01 a$ & $7,28 a$ & $0,81 \mathrm{a}$ \\
\hline 72 & \multicolumn{2}{|c|}{ TMG 4-2 } & $34,61 \mathrm{a}$ & $60,28 \mathrm{a}$ & $5,77 \mathrm{a}$ & $5,17 \mathrm{a}$ & $0,7 \mathrm{a}$ \\
\hline 73 & \multicolumn{2}{|c|}{ TMG 4-3 } & $29,28 \mathrm{ab}$ & $59,61 \mathrm{a}$ & $5,47 a$ & $5,01 \mathrm{a}$ & $0,85 a$ \\
\hline 74 & \multicolumn{2}{|c|}{ TMG 5-1 } & $29,28 \mathrm{ab}$ & $56,94 \mathrm{ab}$ & 3,17 & 2,76 & $0,72 \mathrm{a}$ \\
\hline 75 & \multicolumn{2}{|c|}{ TMG 5-2 } & $30,61 \mathrm{a}$ & $56,28 \mathrm{ab}$ & 3,05 & 2,65 & $0,74 a$ \\
\hline 76 & \multicolumn{2}{|c|}{ TMG 6-1 } & $32,28 a$ & $59,61 a$ & $5,6 a$ & $5,06 a$ & $0,87 \mathrm{ab}$ \\
\hline 77 & \multicolumn{2}{|c|}{ TMG 6-2 } & $34,61 \mathrm{a}$ & $57,94 a$ & 2,49 & 2,23 & $0,79 a$ \\
\hline 78 & \multicolumn{2}{|c|}{ TMG 6-3 } & $35,61 \mathrm{a}$ & $60,28 a$ & $7,46 a$ & $6,62 a$ & $0,87 \mathrm{ab}$ \\
\hline 79 & \multicolumn{2}{|c|}{ TMG 7-1 } & $33,61 \mathrm{a}$ & $58,61 \mathrm{a}$ & $6,99 a$ & $6,29 a$ & $0,77 \mathrm{a}$ \\
\hline 80 & \multicolumn{2}{|c|}{ TMG 7-2 } & $33,28 a$ & $59,61 \mathrm{a}$ & $5,14 a$ & $4,72 \mathrm{a}$ & $0,78 \mathrm{a}$ \\
\hline 81 & \multicolumn{2}{|c|}{ TMG 8-1 } & $29,61 \mathrm{ab}$ & $56,61 \mathrm{ab}$ & 4,47 & 3,97 & $0,83 a$ \\
\hline 82 & \multicolumn{2}{|c|}{ TMG 8-2 } & $32,28 \mathrm{a}$ & $59,61 a$ & 4,41 & 3,88 & $0,7 \mathrm{a}$ \\
\hline \multicolumn{2}{|c|}{ Calibra [CEK] } & $\mathbf{a}$ & 44,00 & 73,83 & 1,82 & 1,42 & 0,29 \\
\hline \multicolumn{2}{|c|}{$\begin{array}{c}\text { SMG }(\mathrm{H})(03) \\
{[\mathrm{CEK}]}\end{array}$} & $\mathbf{b}$ & 36,33 & 63,33 & 6,14 & 5,29 & 0,71 \\
\hline \multicolumn{2}{|c|}{ 05-(16)-1 [CEK] } & $\mathbf{c}$ & 28,50 & 57,50 & 7,40 & 6,56 & 0,78 \\
\hline \multicolumn{3}{|c|}{ LSI } & 6,06 & 6,14 & 3,22 & 2,82 & 0,15 \\
\hline
\end{tabular}

Keterangan: UB (umur berbunga); UPK (umur panen kering); BPT (bobot polong kering per tanaman); BBT (bobot biji kering per tanaman); BBP (bobot biji kering per polong). Notasi "a": lebih baik dibandingkan Calibra[CEK]; " $b$ ": lebih baik dibandingkan SMG(H)(03) [CEK]; "c": lebih baik dibandingkan 05-(16)-1 [CEK]; Tanpa notasi: tidak lebih baik dibandingkan ketiga pembanding.

Pada karakter umur berbunga dan umur panen, dapat diketahui terdapat 16 genotipe yang memiliki umur berbunga dan umur panen kering lebih baik dibandingkan dua pembanding Calibra [CEK] dan SMG(H)(03) [CEK], yaitu genotipe dengan notasi " $a b$ ". Sementara pada karakter hasil yang bernilai ekonomis yaitu karakter bobot biji kering per tanaman dan bobot polong per tanaman, diketahui terdapat 3 genotipe yang memiliki rata-rata hasil lebih baik dibandingkan ketiga pembanding yang diikuti oleh notasi "abc" yaitu genotipe 03(16)(2)-1, Batu-1-1 dan Batu-2 (Tabel 7). Sumber daya genetik ercis penting ditingkatkan untuk menghasilkan varietas unggul baru yang dapat meningkatkan produksi, manajemen, keuntungan, dan peningkatan pemasaran benih ercis (Saxesena et al., 2014). Seleksi dilakukan untuk mencari genotipe ercis yang potensial untuk dikembangkan di dataran rendah. Seleksi dilakukan berdasarkan uji LSI dengan cara membandingkan rata-rata genotipe uji dengan pembanding (cek) yang digunakan.

\section{Kesimpulan}

Hasil penelitian menunjukkan terdapat karakter yang memiliki keragaman luas dan heritabilitas tinggi pada ercis yang ditanam di dataran rendah. Pada penelitian, terpilih 3 genotipe yaitu genotipe 03(16)(2)-1, Batu-1-1 dan Batu-2 yang potensial dikembangkan di dataran rendah.

\section{Ucapan Terima Kasih}

Penulis mengucapkan terima kasih kepada pendanaan penelitian PNBP Hibah Penelitian Dosen Fakultas Pertanian tahun anggaran 2019.

\section{Daftar Pustaka}

Acquaah, G., 2012. Principles of Plant Genetics and Breeding, 2nd ed. Wiley-Blackwell A 
John Wiley \& Sons, Ltd., Publication, Oxford, UK.

Barcchiya, J., Naidu, A.K., Mehta, A.K., Upadhyay, A., 2018. Genetic variability, heritability and genetic advance for yield and yield components in pea (Pisum sativum L.) 6, 3324-3327.

Dahl, W.J., Foster, L.M., Tyler, R.T., 2012. Review of the health benefits of peas (Pisum sativum L.). Br. J. Nutr. 108, S3-S10. https://doi.org/10.1017/S000711451200085 2

Handayani, T., Hidayat, I., 2012. Keragaman genetik dan heritabilitas beberapa karakter utama pada kedelai sayur dan implikasinya untuk seleksi perbaikan produksi. J. Hort. 22, 327-333.

Hapsari, R.T., 2014. Pendugaan keragaman genetik dan korelasi antara komponen hasil kacang hijau berumur genjah. Bul. Plasma Nutfah 20, 51-58. https://doi.org/10.21082/blpn.v20n2.2014. p51-58

Herawati, R., Purwoko, B.S., Dewi, I.S., 2009. Keragaman genetik dan karakter agronomi galur haploid ganda padi gogo dengan sifat-sifat tipe baru hasil kultur antera. J. Agron. Indones. 37, 87-94.

Jaiswal, N.K., Gupta, A.K., Dewangan, H., Lavanya, G.R., 2013. Genetic variability analysis in field pea (Pisum sativum L.). Int. J. Sci. Res. 14, 2319-7064.

Jameela, H., Sugiharto, A.N., Soegianto, A., 2014. Keragaman genetik dan heritabilitas karakter komponen hasil pada populasi F2 buncis (Phaseolus vulgaris L.) hasil persilangan varietas introduksi dengan varietas lokal. J. Protan. 2, 324-329.

Jhanavi, D.R., Patil, H.B., Justin, P., Hadimani, R.H.P., Mulla, S.W.R., Sarvamangala, C., 2018. Genetic variability, heritability and genetic advance studies in french bean (Phaseolus vulgaris L.) genotypes. Indian J. Agric. Res. 52, 162-166. https://doi.org/10.18805/IJARe.A-4923

Katoch, V., Singh, P., Devi, M.B., Sharma, A., Sharma, G.D., Sharma, J.K., 2016. Study of genetic variability, character association, path analysis and selection parameters for heterotic recombinant inbred lines of garden peas (Pisum sativum var. hortense L.) under mid-hill conditions of Himachal Pradesh, India. Legum. Res. 39, 163-169. https://doi.org/10.18805/lr.v0iOF.6775
Kementerian Pertanian, 2017. Statistik mikro sektor pertanian. Pusat Data dan Sistem Informasi Pertanian, Kementerian Pertanian.

Larmure, A., Munier-Jolain, N.G., 2019. High temperatures during the seed-filling period decrease seed nitrogen amount in pea (Pisum satioum L.): evidence for a sink limitation. Front. Plant Sci. 10, 1-11. https://doi.org/10.3389/fpls.2019.01608

Peterson, R.G. 1994. Agricultural Field Experiment Design and Analysis. Mecel Dekker. Inc. New York.

Purnamaningsih, S.L., Saptadi, D., Waluyo, B., 2019. Pengembangan ercis (Pisum sativum L.) jenis biji kering (dry peas) berdasarkan seleksi genotip berdaya hasil tinggi pada polong dan biji, in: Brotodjojo, R.R.R., Puspitaningrum, D.A., Widodo, R.A. (Eds.), Prosiding Seminar Nasional "Pembangunan Pertanian Indonesia dalam Memperkuat Lumbung Pangan, Fundamental Ekonomi, dan Daya Saing Global." Fakultas Pertanian Universitas Pembangunan Nasional "Veteran" Yogyakarta, Yogyakarta, pp. 1140-1147.

Sa'diyah, N., Widiastuti, M., Ardian, 2013. Keragaan, keragaman, dan heritabilitas karakter agronomi kacang panjang (Vigna unguiculata) generasi F1 hasil persilangan tiga genotipe. J. Agrotek Trop. 1, 32-37.

Sari, G.N., Lestari Purnamaningsih, S., Saptadi, D., Zanetta, C.U., Waluyo, B., Sari, G.N., Purnamaningsih, S.L., Saptadi, D., Zanetta, C.U., Waluyo, B., 2019. Penampilan dan jarak genetik galur ercis yang diseleksi dari potensi genetik lokal Indonesia berdasarkan karakter agromorfologi, in: Brotodjojo, R.R.R., Puspitaningrum, D.A., Widodo, R.A. (Eds.), Prosiding Seminar Nasional "Pembangunan Pertanian Indonesia dalam Memperkuat Lumbung Pangan, Fundamental Ekonomi, dan Daya Saing Global." Fakultas Pertanian Universitas Pembangunan Nasional "Veteran" Yogyakarta, Yogyakarta, pp. $1148-1159$.

Saxesena, R.R., Vidyakar, V., Vishwakarma, M.K., Yadav, P.S., Meena, M.L., Lal, G.M., 2014. Genetic variability and heritability analysis for some quantitative traits in field pea (Pisum sativum L.). The Bioscan 9, 895898.

Selvaraj, I., Pothiraj, N., Thiyagarajan, K., 
Bharathi, M., Rabindran, R., 2011. Genetic parameters of variability, correlation and path-coefficient studies for grain yield and other yield Attributes among rice blast disease resistant genotypes of rice (Oryza sativa L.). African J. Biotechnol. 10, 33223334. https://doi.org/10.5897/ajb10.2575

Sharma, J.R. 2006. Statistical and Biometrical Technique in Plant Breeding. Reprint. New Age International Ltd. Publishers. New Delhi.

Singh, RK and BD Chaudary. 1977. Biometrical Methods in Quantitative Genetics Analysis. Kalyani Publishers. Indiana New Delhi.

Stansfield, W.D., 1991. Schaum's Outline of Theory and Problems of Genetics. McGraw-Hill, New York.

Syukur, M., Sujiprihati, S., Yunianti, R., Kusumah, D.A., 2011. Pendugaan ragam genetik dan heritabilitas karakter komponen hasil beberapa genotip cabai. J. Agrivigor 10, 148-156.
Ton, A., Karakoy, T., Anlarsal, A.E., Turkeri, M., 2018. Genetic variability, heritability and path analysis in field pea (Pisum sativum L.). Fresenius Environ. Bull. 27, 2275-2279.

UPOV, 2009. Guideline for The Conduct of Tests for Distinctness, Uniformity, and Stability of Pea (Pisum sativum L.). Geneva, Switzerland.

Waluyo, B., Saptadi, D., Lestari Purnamaningsih, S., 2019. Seleksi genotip potensial ercis (Pisum sativum L.) fase polong hijau [kacang polong (green peas) berbiji besar dan hasil tinggi untuk pelepasan varietas unggul, in: Brotodjojo, R.R.R., Puspitaningrum, D.A., Widodo, R.A. (Eds.), Prosiding Seminar Nasional "Pembangunan Pertanian Indonesia dalam Memperkuat Lumbung Pangan, Fundamental Ekonomi, dan Daya Saing Global." Fakultas Pertanian Universitas Pembangunan Nasional "Veteran" Yogyakarta, Yogyakarta, pp. 1131-1139. 